\title{
INTERNALISASI NILAI-NILAI RELIGIUS BERBASIS MULTIKULTURAL DALAM MEMBENTUK INSAN KAMIL
}

\author{
Muh. Khoirul Rifa 'i \\ (UIN Sunan Ampel Surabaya)
}

\begin{abstract}
Abstrak:
Globalisasi membawa dampak pada persaingan keunggulan di aspek-aspek kehidupan. Dalam konteks pendidikan, persaingan mendapatkan pendidikan terbaik dalam prestasi akademis telah menjadi semacam kompetisi. Di sinilah muncul tuntutan dari beberapa pihak pengguna pendidikan untuk memunculkan keunggulan manusia melalui konsep insan kamil di dunia pendidikan. Insan kamil dapat dibentuk jika manusia saling menghormati dan menjalankan ajaran agamanya dengan murni dan konsekuen. Nilai religius multikultural merupakan nilai urgen untuk diinternalisasikan kepada peserta didik karena nilai tersebut akan mampu menjadikan peserta didik menjadi lebih toleran dan lebih religius bahkan mengamalkan ajaran agamanya dan menyentuh afeksi dan psikomotoriknya. Kertas kerja ini membahas tentang Internalisasi nilai religius multikultural dengan membentuk budaya religius multikultural sehingga pada akhirnya anak didik akan terbiasa mengamalkan nilai-nilai religius dan akan menjadi anak didik yang menghormati sesamanya bahkan dengan yang lain agama.
\end{abstract}

Kata Kunci: Nilai-Nilai Religius, Multikultur, Insan Kamil.

\begin{abstract}
:
Globalization brings competition in life aspects. In terms of education, rivalry in going to the best education for best academic achievement provider has become a kind of competition. This emerges demands from education users to emerge human excellence through the concept of insan kamil (honorific personality) in education. Honorific personality can be forms when human being respect each other and practice religions purely and consequently. The religious-multicultural values are urgently internalized to students as it promotes tolerance and religiousity so that the religious practice is alive in students' affective and psychomotoric domains. This working paper is dealing with internalization process of religious-multicultural values by creating the culture of religiousity and multiculture to form the habit of respecting, despite with those from different religions.
\end{abstract}

Keywords: Religious Values, Multiculture, Honorific Personality. 


\section{A. Pendahuluan}

Pada era globalisasi ini, kesadaran orang tua akan pentingnya pendidikan yang berkualitas bagi anak-anaknya semakin meningkat, sekolah yang berkualitas semakin dicari. Orang tua tidak peduli apakah sekolah negeri ataupun swasta. Sekolah-sekolah yang bermutu dan bermuatan agama, menjadi pilihan pertama bagi orang tua di berbagai kota. Orang tua menyadari benar akan pentingnya pendidikan yang bernuansa keagamaan bagi anak-anaknya dalam rangka untuk menangkal pengaruh yang negatif di era globalisasi. Meskipun demikian, ada juga orang tua yang menyekolahkan anaknya tanpa memperhatikan aspek keagamaan dan lebih mementingkan mutu sekolah yang bersangkutan.

Kondisi yang terjadi demikian tersebut dikarenakan kurangnya kesadaran orang tua dalam mendidik anaknya, sehingga anaknya akan berkembang sendiri dengan lebih liar dan akan mengakibatkan penyimpangan. Solusi yang biasanya diambil oleh orang tua adalah memasukkan anaknya ke pesantren atau menyekolahkan anaknya ke sekolah yang masuk satu hari penuh. Namun, dalam hal ini pesantren nampaknya kalah saing dengan sekolah umum yang berlabel islam. Salah satu indikator kemenangan persaingan tersebut adalah banyak beridiri SDI atau sekolah yang berlabel islam.

Kesadaran orang tua akan pendidikan Islam dan penanaman nilai-nilai Islam bagi anak-anaknya nampaknya sesuai dengan pandangan Jalaluddin. Menurut Jalaluddin yang dikutip Kartika Nur Fathiya, mengatakan bahwa pengenalan ajaran agama sangat berpengaruh dalam pembentukan jiwa anak. Jiwa dan kecerdasan spiritual anak akan lebih terlatih dan terbentuk dengan pembiasaan setiap harinya. ${ }^{1}$

Pada dasarnya tingginya kesadaran agama berpengaruh pada aktualisasi jiwa seseorang dalam kehidupan sehari-hari yang dimanifestasikan dalam bentuk kegiatan-kegiatan olah kejiwaan dan olah spiritual seperti saling tolong menolong dengan sesama, menghargai sesama, dan menginternalisasikan nilai-nilai universal. ${ }^{2}$ Dalam agama, nilai-nilai universalitas biasanya berupa nilai sosial dan nilai moral, misalnya bersedekah, membantu orang menyeberang dan sebagainya.

Internalisasi nilai agama merupakan hal yang penting dilakukan dalam suatu lembaga pendidikan. Internalisasi nilai agama merupakan hal yang urgen dan harus terjadi karena dalam internalisasi nilai agama terdapat hubungan timbal balik antara pendidik dan peserta didik. Di mana dalam hal ini, pendidik tidak hanya berfungsi sebagai pengajar saja, namun juga sebagai pembimbing dan muaddib atau murabbi bagi peserta didik, yakni sebagai orang yang bertugas

${ }^{1}$ Kartika Nur Fathiya, Problem, Dampak, dan Solusi Transformasi Nilai-Nilai Agama pada Anak Prasekolah (Dinamika Pendidikan No. 1/ Th. XIV / Mei 2007), 102-103.

2 Marzuki. Pendidikan Agama Islam di Perguruan Tinggi di Perguruan Tinggi Umum dan Pemberdayaan Masyarakat Indonesia (Cakrawala Pendidikan no1 tahun XVI Februari 1997), 45. 
membimbing, mengarahkan, menunjukkan serta menginternalisasikan nilai-nilai agama kepada anaknya. ${ }^{3}$

Seorang pendidik bertugas tidak hanya memberikan ilmu (knowledge) kepada peserta didik, tetapi juga mentransformasikan nilai-nilai (value) pada peserta didik. Salah satu komponen yang sangat penting dalam sistem kependidikan adalah pendidik, karena ia yang akan mengantarkan dan membimbing bahkan mengarahkan anak didik pada tujuan yang telah ditentukan, bersama komponen yang lain terkait dan lebih bersifat komplementatif (pelengkap). ${ }^{4}$

Peserta didik merupakan komponen yang tidak kalah pentingnya dalam proses pembelajaran. Hubungan antara pendidik dan peserta didik dalam proses pembelajaran ibarat hubungan orang tua dengan anaknya. Maka secara spiritual sebagaimana dikatakan di atas, bahwa pendidik berkewajiban mendidik peserta didik dan menanamkan nilai-nilai agama kepadanya melalui proses pendidikan dan pembiasaan perilaku di lingkungan sekolah. Nilai-nilai tersebut meliputi nilai iman, ibadah, akhlak, dan sosial dan lain sebagainya.

\section{B. Konsep Nilai Religius}

Jika dilihat dari bahasanya nilai religius berasal dari gabungan dua kata, yaitu kata nilai dan kata religius. Kata nilai dapat diartikan secara etimologis dan terminologis. Dari segi etimologis nilai adalah harga, derajat. ${ }^{5}$ Nilai adalah ukuran untuk memilih tindakan atau upaya kegiatan dan tujuan tertentu. ${ }^{6}$ Sedangkan secara terminologis dapat dilihat berbagai rumusan pakar nilai. Tapi perlu ditekankan bahwa nilai adalah mutu empirik yang kadang-kadang sulit atau tidak bisa didefinisikan. ${ }^{7}$ Namun, Louis Katsoff mengatakan bahwa kenyataan bahwa nilai tidak bisa diartikan dengan baik bukan berarti nilai tidak bisa dipahami oleh khalayak kehidupan. ${ }^{8}$

Menurut Fraenkel, yang dikutip Ekosusilo, dinyatakan bahwa nilai dapat diartikan sebagai sebuah ide atau pemikiran mengenai apa yang dianggap urgen bagi seseorang dalam alur kehidupannya. ${ }^{9}$ Alport sebagaimana yang dikutip oleh Mulyana, mengemukakan bahwa nilai adalah keyakinan yang membuat seseorang berperilaku atas dasar pilihannya atau dalam kata lain keyakinan sebagai dasar

${ }^{3}$ Ahmad Tafsir, Ilmu Pendidikan dalam Perspektif Islam (Bandung: Remaja Rosda Karya, 1992), 74-75. Sulistiyorini, Manajemen Pendidikan Islam (Surabaya: eLKAF, 2006), 51.

${ }^{4}$ Khoiron Rosyadi, Pendidikan Profetik (Yogyakarta: Pustaka Pelajar, 2004), 172.

5 JS Badudu, Sutan Muhammad Zain, Kamus Umum Bahasa Indonesia (Jakarta: Pustaka Sinar Harapan, 1996), 944.

${ }^{6}$ Khoiron Rosyadi, Pendidikan Profetik, Cet.1 (Yogyakarta: Pustaka Pelajar, 2004), 114.

${ }^{7}$ Abdul Latif, Pendidikan Berbasis Nilai Kemasyarakatan (Bandung: Refika Aditama, 2006), 69.

8 Louis O.Katsoff, Elements of Philosophy, terj. Soejono Soemargono (Yogyakarta: Tiara Wacana, 1989), 335.

${ }^{9}$ Madyo Ekosusilo, Hasil Penelitian Kualitatif Sekolah Unggul Berbasis Nilai: Studi Multi Kasus di SMAN 1, SMA Regina Pacis, dan SMA al-Islam 01 Surakarta (Sukoharjo: UNIVET Bantara Press, 2003), 22. 
pilihan tindakan. ${ }^{10}$ Selain itu, kebenaran sebuah nilai pada dasarnya tidak menuntut adanya pembuktian empirik, namun lebih terkait dengan pemahaman, kesadaran, trust dan apa yang dikehendaki atau tidak dikehendaki, disenangi atau tidak disenangi oleh seseorang.

Menurut Kuperman, yang dikutip Mulyana mengemukakan bahwa "nilai adalah patokan normatif yang mempengaruhi manusia dalam menentukan pilihannya di antara cara-cara tindakan alternatif”. 11 Menurut Hans Jonas, yang juga dikutip oleh Mulyana menyatakan nilai adalah "sesuatu yang ditunjukkan dengan kata ya".12 Sedangkan menurut Kuchlohn, sebagaimana juga dikutip Mulyana mengatakan bahwa "nilai sebagai konsepsi (tersirat atau tersurat, yang sifatnya membedakan individu atau ciri-ciri kelompok) dari apa yang diinginkan, yang mempengaruhi pilihan terhadap cara, tujuan antara dan tujuan akhir tindakan".13

Jadi pada intinya nilai merupakan suatu keyakinan sebagai dasar pilihan tindakan yang menjadikan hidupnya pada masa yang akan datang mempunyai makna atau tidak, serta yang akan menjadi bahan pemikirannya untuk mencapai tujuannya.

Orang yang mempelajari suatu nilai-nilai sangat urgen untuk mempelajari perilaku individu atau kelompok, karena nilai merupakan dasar untuk memahami sikap dan motivasi serta mempengaruhi persepsi si pemilik nilai. Individuindividu dalam suatu organisasi dengan gagasan yang dirancang sebelumnya mengenai apa yang "seharusnya" dan "tidak seharusnya". Tentu saja gagasangagasan itu tidak bebas nilai. ${ }^{14}$ Bahkan Robbins menambahkan bahwa nilai itu mempengaruhi afektif dan psikomotor manusia. ${ }^{15}$

Kata religius biasa diartikan dengan kata agama, namun juga bisa diartiken sebagai keberagamaan. Agama, menurut Harun Nasution dalam pendapatnya yang dikutip oleh Abuddin Nata, tersusun dari dua kata, a=tidak dan gama=pergi, jadi agama artinya tidak pergi, tetap di tempat, diwarisi secara turun temurun. ${ }^{16}$ Secara istilah, agama, menurut Elizabeth sebagaimana yang dikutip Abuddin Nata, gejala yang begitu sering terdapat dimana-mana sehingga sedikit membantu usaha-usaha kita untuk membuat abstraksi ilmiah.

Frazer mengartikan agama, sebagaimana dikutip Nuruddin adalah sistem kepercayaan yang tidak stagnan dan berkembang sesuai dengan tingkat kognisi seseorang. ${ }^{17}$ Clifford Geertz mengemukakan, sebagaimana dikutip Roibin, agama dan spirit itu beda sedangkan spirit adalah semangat, pada dasarnya telah terjadi hubungan yang akrab antara agama sebagai sumber nilai dan agama sebagai

${ }^{10}$ Rohmat Mulyana, Mengartikulasikan Pendidikan Nilai (Bandung: Alfabeta, 2004), 9.

${ }^{11}$ Mulyana, Mengartikulasikan Pendidikan, 9.

12 Mulyana, Mengartikulasikan Pendidikan, 9-10.

13 Mulyana, Mengartikulasikan Pendidikan, 9-10.

${ }^{14}$ S.P. Robbins, Organizational Behaviour (New Jersey: Prentice Hall, Inc, 1991), 158.

${ }^{15}$ Robbins, Organizational Behaviour, 159.

16 Abuddin Nata, Metodologi Studi Islam (Jakarta: Raja Grafindo Persada, 2003), 9.

17 Nuruddin, dkk, Agama Tradisional: Potret Kearifan Hidup Masyarakat Samin dan Tengger (Yogyakarta: LKIS, 2003), 126. 
sumber kognitif atau pengetahuan. Pertama, agama merupakan dasar bagi tindakan manusia (pattern for behaviour). Sebagai dasar tindakan agama menjadi arah bagi tindakan manusia. Kedua, agama merupakan pola dari tindakan manusia (pattern of behaviour). Sebagai pola ini agama dianggap sebagai hasil dari cipta, rasa dan karsa manusia yang tidak jarang telah dipengaruhi oleh kekuatan mistis. ${ }^{18}$

Agama dalam perspektif yang kedua ini sering dipahami sebagai bagian dari sistem kebudayaan, ${ }^{19}$ yang tingkat efektifitas fungsi ajarannya kadang tidak kalah dengan agama formal. Namun agama merupakan sumber nilai yang tetap harus dipertahankan aspek otentitasnya. Jadi di satu sisi, agama dipahami sebagai hasil menghasilkan dan berinteraksi dengan budaya. Pada sisi lain, agama juga tampil sebagai sistem nilai yang mengarahkan bagaimana manusia berperilaku.

Jadi agama adalah ajaran yang berasal dari Tuhan atau renungan manusia yang terkandung dalam kitab suci yang turun temurun diwariskan oleh suatu generasi ke generasi berikutnya dengan tujuan untuk memberi tuntunan dan pedoman hidup bagi manusia agar mencapai kebahagiaan dunia dan akhirat yang didalamnya mencakup kepercayaan kepada kekuatan ghaib yang selanjutnya menimbulkan respon emosional dan keyakinan bahwa kebahagiaan hidup tersebut tergantung pada adanya hubungan baik dengan kekuatan tersebut.

Jadi yang dimaksud nilai religius atau nilai agama adalah konsepsi yang tersurat maupun tersirat yang ada dalam agama yang mempengaruhi perilaku seseorang yang menganut agama tersebut yang mempunyai sifat hakiki dan datang dari Tuhan, juga kebenarannya diakui mutlak oleh penganut agama tersebut.

Nilai religius merupakan salah satu dari berbagai klasifikasi nilai di atas. Nilai religius bersumber dari agama dan mampu merasuk ke dalam intimitas jiwa. Nilai religius perlu ditanamkan dalam lembaga pendidikan untuk membentuk kepribadian muslim yang mantab dan kuat di lembaga pendidikan tersebut. Di samping itu, penanaman nilai religius ini penting dalam rangka untuk memantabkan etos kerja dan etos ilmiah seluruh civitas akademika yang ada di lembaga pendidikan tersebut. Selain itu, juga supaya tertanam dalam diri tenaga kependidikan bahwa melakukan kegiatan pendidikan dan pembelajaran pada anak didik bukan semata-mata bekerja untuk mencari uang, tetapi merupakan bagian dari ibadah.

\section{Konsep Plural-Multikultural}

Nilai religius yang plural-multikultural itu yang perlu ditanamkan supaya seorang manusia bisa menjadi insan kamil. Secara bahasa, kata pluralis berasal dari bahasa Inggris plural yang berarti beraneka ragam. Secara istilah pluralisme secara substansial termanifestasi dalam sikap serta kesadaran untuk saling mengakui sekaligus menghargai, toleransi, menghormati, memelihara, dan

${ }^{18}$ Roibin, Relasi Agama \& Budaya Masyarakat Kontemporer (Malang: UIN Maliki Press, 2009), 75.

${ }^{19}$ Nursyam, Islam Pesisir (Yogyakarta: LKIS, 2005), 1.

Jurnal Pendidikan Agama Islam

Volume 4 Nomor 1Mei 2016

ISSN(p) 2089-1946\& ISSN(e) 2527-4511

Hal. 120 - 133 
bahkan mengembangkan atau memperkaya keadaan yang bersifat plural, jamak atau banyak. ${ }^{20}$ Menurut Nurcholish Madjid sebagaimana dikutip oleh Budy Munawar Rahman, pluralisme harus dipahami sebagai upaya membentuk keragaman atau diistilahkan sebagai "genuine engagement of diversities withi the bond of civility". ${ }^{21}$

Dalam konteks pemahaman Islam, keberagaman juga terjadi. Keberagaman tersebut pada gilirannya memunculkan pola-pola artikulasi keberagaman, yang menurut Azra, sebagaimana dikutip Muhaimin, dikelompokkan dalam 3 tipologi, yaitu (1) Substansialisme yang lebih mementingkan substansi atau isi daripada label atau symbol-simbol eksplisit; (2) formalisme/legalisme yang cenderung sangat literal atau ketaatan formal dan hokum agama, diekspreksikan dalam bentuk sangat lahiriyah semacam symbol keagamaan; (3) Spiritualisme yang lebih menekankan kepada pengembangan sikap batiniah, melalui keikutsertaan dalam kelompok spiritual mistik, tasawuf, tarekat bahkan kelompok kultus. ${ }^{22}$ Maka dari itu, keberagaman inilah yang akan menjadi kekayaan dan modal dasar pengembangan pendidikan Islam.

Kata multikultural menurut bahasa dapat berarti 'keragaman budaya'. ${ }^{23}$ Kultur atau budaya merupakan cipta, karya dan karsa manusia yang tidak diturunkan secara genetis dan bersifat khusus. Kultur identik dengan tempat satu dan tempat yang lainnya. ${ }^{24}$ Aspek 'keragaman' yang menjadi inti dari konsep multikultural dan kemudian berkembang menjadi sebuah gerakan yang disebut dengan multikulturalisme, ${ }^{25}$ merupakan gerakan yang bukan hanya menuntut pengakuan terhadap semua perbedaan yang ada, tetapi juga bagaimana keragaman atau perbedaan yang ada dapat diperlakukan sama dalam arti tidak ada perbedaan yang mendasar yang menyebabkan perbedaan perlakuan. Dalam

20 Kautsar Azhari Noer, "Menyemarakkan Dialog Agama (Perspektif Kaum Sufi)", dalam Edy.A.Effendi (ed), Dekonstruksi Islam Madzhab Ciputat (Bandung: Zaman Wacana Mulia, 1999), 872.

${ }^{21}$ Budhy Munawar Rahman, Islam Pluralis, (Jakarta : Paramadina, 2001), 31.

22 Muhaimin, Arah Baru Pengembangan Pendidikan Islam, (Bandung: Tarsito, 2003), 56.

23 Scott Lash dan Mike Featherstone (ed.), Recognition And Difference: Politics, Identity, Multiculture (London: Sage Publication, 2002), 2.

${ }^{24}$ M. Ainul Yaqin, Pendidikan Multikultural (Cross-Cultural Understanding untuk Demokrasi dan Keadilan) (Yogyakarta: Pilar Media, 2005), 9.

${ }^{25} \mathrm{Ada}$ tiga istilah yang sering digunakan untuk menggambarkan masyarakat yang memiliki karakter beragam, baik dalam aspek keagamaan, ras, bahasa, maupun budaya yang berbeda. Istilah tersebut adalah pluralitas (plurality), keragaman (diversity), dan multikultural (multicultural). Ketiga istilah ini sesungguhnya tidak merepresentasikan hal yang sama, walaupun semuanya mengacu kepada adanya 'ketidaktunggalan'. Konsep pluralitas mengandaikan adanya 'hal-hal yang lebih dari satu' (many), sedangkan keragaman menunjukkan bahwa keberadaan yang 'lebih dari satu' itu berbeda-beda, heterogen dan bahkan tak dapat disamakan. Apabila pluralitas sekadar menunjukkan adanya kemajemukan, multikulturalisme memberikan penegasan bahwa dengan segala perbedaannya itu mereka adalah sama di dalam ruang publik. Lihat Charles Taylor, "The Politics of Recognation" dalam Amy Gutman, Multiculturalism, Examining the Politics of Recognition (Princenton: Princenton University Press, 1994), 18. 
kaitan ini, terdapat tiga hal pokok yang menjadi aspek mendasar dari multikulturalisme, yakni: Pertama, masalah harkat dan martabat manusia adalah sama. Kedua, kebudayaan yang berbeda-beda, oleh karena itu membutuhkan hal yang Ketiga, yaitu kesadaran untuk mengakui dan menghormati harkat, dan martabat serta perbedaan kebudayaan tersebut.

Aspek utama yang paling didahulukan dalam membudayakan multikultural adalah kesadaran untuk menerima dan menghormati pemeluk agama lain, kelompok lain, etnis lain bahkan tidak membeda-bedakan antar etnis dalam konteks harga diri dan keadilan juga HAM. Manusia yang hidup dalam suatu komunitas mempunyai harkat dan martabat yang menyatu dengan entitas budayanya masing-masing (yang bersifat dinamis dan khas), merupakan dimensi yang sangat urgen dalam pembudayaan nilai multikultural.

Berangkat dari pemahaman yang demikian, maka sewajarnya nilai-nilai multikulturalisme dapat terintegrasi secara jelas dalam agenda pendidikan Islam. Adapun pendidikan Islam memberikan tuntunan dan teladan. ${ }^{26}$

\section{Konsep Insan Kamil}

Insan kamil berasal dari bahasa Arab, yaitu dari dua kata Insan dan kamil. Secara bahasa insan kamil dapat berarti manusia yang sempurna. Dengan demikian, insan kamil berarti manusia yang sempurna. Dalam bahasa Arab kata insan mengacu kepada sifat manusia yang penuh dengan kelupaan dan kesalahan lainnya. Selanjutnya kata insan digunakan sebagai kata yang menunjukkan pada arti manusia yang secara langsung mengarah pada hakikat manusia. Padahal masih banyak kata-kata yang lain, seperti kata basyar, Abdullah, nas dan sebagainya

Ungkapan kamil dapat pula berarti suatu kondisi yang sempurna, dan digunakan untuk menunjukkan pada sempurnanya zat dan sifat, dan hal itu terjadi melalui terkumpulnya dan meningkatnya sejumlah potensi dan kelengkapan seperti ilmu, dan sekalian sifat yang baik lainnya. Beberapa tokoh tasawuf menjelaskan tentang konsep insan kamil dalam ajarannya, yaitu:

Dalam kitab Futuhatil Makkiyah, Muhyiddin Ibnu 'Arabi mengungkapkan bahwa insan kamil ialah manusia yang sempurna dari segi bentuk dan kompetensinya. Kesempurnaan dari segi bentuknya ialah karena insan kamil merupakan manifestasi sempurna dari citra Tuhan, yang pada dirinya tercermin nama-nama dan sifat Tuhan yang diamalkan secara secara utuh. Adapun kesempurnaan dari segi kompetensinya ialah karena dia telah mencapai tingkat kesadaran tertinggi, yakni mengalami kesatuan esensinya dengan Tuhan, yang disebut ittihad. ${ }^{27}$

Kesempurnaan manusia yang mempunyai gelar insan kamil itu pada dasarnya disebabkan karena pada Tuhan telah menyatu dengan dirinya melalui hakikat Muhammad (al-haqiqah al-Muhammadiyah). Nur Muhammad

\footnotetext{
${ }^{26}$ Hasan Langgulung, Asas-asas Pendidikan Islam (Jakarta: Pustaka al-Husna, 1993), 62.

27 Yunasril Ali, Manusia Citra Ilahi (Jakarta: Paramadina, 1997), 60.
} 
merupakan wadah penyatuan bagi Tuhan yang sempurna. ${ }^{28}$ Jadi, dari satu sisi, insan kamil merupakan wadah tajalli Tuhan yang paripurna, sementara disisi lain, ia merupakan refleksi dari segenap jagad raya, karena pada dirinya terproyeksi secara komprehensif semua realita kehidupan baik yang fisik maupun yang metafisik.

Al-Jili mengatakan bahwa insan kamil merupakan diri Nabi Muhammad SAW sebagai sebuah contoh manusia ideal, dimana pada sejatinya sifat-sifat Nabi Muhammad yaitu siddiq, amanah, tabligh dan fathonah itu tidak mampu dialihkan atau dipikul oleh para sahabat. Jati diri Muhammad yang demikian tidak semata-mata dipahami dalam pengertian Muhammad SAW sebagai manusia, tetapi juga sebagai nur (cahaya/roh) Ilahi yang menjadi pangkal dan poros kehidupan di alam semesta ini. Tuhan yang mengenal dirinya sendiri kemudian memancarkan nur Ilahi kemudian menjadi sebuah dzat yang dikenal sebagai Nur Muhammad oleh kalangan sufi, disamping terdapat dalam diri Muhammad juga dipancarkan Allah SWT ke dalam diri Nabi Adam AS dan nabi sesudahnya.

Dalam pengertian demikian, insan kamil terkait dengan pandangan mengenai sesuatu yang dianggap mutlak, yaitu Tuhan. Yang Mutlak tersebut dianggap mempunyai sifat-sifat tertentu, yakni yang baik dan sempurna. Sifat sempurna inilah yang patut ditiru oleh manusia. Seseorang yang makin memiripkan diri pada sifat sempurna dari Yang Mutlak tersebut, maka makin sempurnalah dirinya. Bagi al-Jili, manusia dapat mencapai jati diri yang sempurna melalui latihan rohani dan pendakian mistik, bersamaan dengan turunnya Yang Mutlak ke dalam manusia melalui berbagai tingkat. Latihan rohani ini diawali dengan manusia bermeditasi tentang nama dan sifat-sifat Tuhan, dan mulai mengambil bagian dalam sifat-sifat Illahi serta mendapat kekuasaan yang luar biasa.

Pembagian insan kamil dilakukan menjadi tiga tingkatan.

1. Tingkat permulaan (al-bidāyah). Pada tingkat ini insan kamil mulai dapat merealisasikan nama-nama Allah dan sifat ketuhanan pada diri Allah.

2. Tingkat menengah (at-tawasut). Pada tingkat ini insan kamil harus berperan sebagai realitas kasih Tuhan (al-haqāiq ar-rahmāniyah). Sementara itu, pengetahuan yang dimiliki oleh insan kamil pada tingkat ini juga telah meningkat dari pengetahuan manusia biasa.

3. Tingkat terakhir (al-khitām). Pada tingkat ini insan kamil telah dapat merealisasikan citra Tuhan secara utuh. Dengan demikian pada insan kamil sering terjadi hal-hal yang di luar akal manusia atau biasa disebut dengan karomah. ${ }^{29}$

Manusia sempurna (Insan Kamil) yakni mempunyai ciri-ciri sebagai berikut :

1. Jism yang sehat serta kuat dan mempunyai kompetensi.

${ }^{28}$ Asmaran, Pengantar Studi Tasawuf (Jakarta:PT Raja Grafindo Persada, 2002), 354.

${ }^{29}$ Ali, Manusia Citra Ilahi , 56. 
Orang Islam perlu memiliki jism yang sehat serta kuat, terutama berhubungan dengan dakwah agama Islam. Dalam surah al-Anfal: 60, disebutkan agar orang islam mempersiapkan kekuatan dan pasukan berkuda untuk menghadapi musuh-musuh Allah. Jasmani yang sehat serta kuat berkaitan pula dengan menguasai keterampilan yang diperlukan dalam mencari rezeki untuk kehidupan.

2. Cerdas serta pintar.

Cerdas ditandai oleh adanya kemampuan problem solving dan problem learning dengan cepat dan tepat, sedangkan pintar ditandai oleh banyak memiliki pengetahuan (banyak memiliki informasi). Didalam surah az-Zumar: 9 disebutkan sama antara orang yang mengetahui dan orang yang tidak mengetahui, sesungguhnya hanya orang yang berakallah yang dapat menerima pelajaran.

3. Spirtual yang berkualitas

Spiritual yang berkualitas tinggi adalah spiritual yang penuh berisi iman kepada Allah. Hatinya selalu taqwa kepada Allah. Hati yang iman itu ditandai bila orangnya shalat, ia shalat dengan khusuk, bila mengingat Allah hatinya tenang dan bila disebut nama Allah bergetar hatinya bila dibacakan kepada mereka ayat-ayat Allah, orang-orang tersebut bertambah imannya. ${ }^{30}$

Sifat-sifatnya manusia yang sempurna terdiri dari: Keimanan, Ketaqwaan, Keadaban, Keilmuan, Kemahiran, Ketertiban, Kegigihan dalam kebaikan dan kebenaran, Persaudaraan, Persepakatan dalam hidup, Perpaduan umah. Untuk cara-cara mencapainya ialah dengan car istigfar kepada Allah SWT, ikhlas, sabar, cermat, optimis serta Syukur.

Nabi Muhammad Saw terkenal dengan sebutan yaitu teladan insan kamil atau istilah populernya di dalam Q.S. al- Ahdzab/33:21:

"Sesungguhnya telah ada pada (diri) Rasulullah itu suri teladan yang baik bagimu (yaitu) bagi orang yang mengharap (rahmat) Allah dan (kedatangan) hari kiamat dan Dia banyak menyebut Allah."

Interpretasi tata nilai tersebut tidak dilakukan semaunya, berstandard seenaknya, tapi juga memberikan kepada kita, Rasulullah SAW yang menjadi uswah hasanah. Rasulullah SAW merupakan insan kamil, manusia paripurna, yang tidak ada satupun sisi-sisi kemanusiaan yang tidak disentuhnya selama hidupnya. Ia adalah ciptaan terbaik yang kepadanya kita merujuk akan akhlaq yang mulia. Sebagaimana firman Allah SWT:

"Dan sesungguhnya engkau (Muhammad) benar-benar memiliki akhlaq yang mulia." (QS. Al-Qolam:4)

Nur atau cahaya yang menjadi sosok diri Muhammad adalah sebagai seorang Rasulullah Rahmatan Lil'alamin. Muhammad adalah nabi akhir zaman dan karena itu menjadi penutup semua nabi terdahulu yang diutus untuk menjadi saksi kehidupan manusia dan pembawa berita tentang kehidupan mendatang di akhirat sesuai dengan firman Allah SWT.,

${ }^{30}$ Ali, Manusia Citra Ilahi , 56.

Jurnal Pendidikan Agama Islam

Volume 4 Nomor 1 Mei 2016

ISSN(p) 2089-1946\& ISSN(e) 2527-4511

Hal. 124 - 133 
"Sesungguhnya telah datang kepadamu cahaya dari Allah, dan kitab yang menerangkan. Dengan kitab itu Allah menunjuki orang-orang yang mengikuti keridaan-Nya ke jalan keselamatan, dan (dengan kitab itu pula) Allah mengeluarkan orang-orang itu dari gelap gulita kepada cahaya yang terang benderang dengan seizin-Nya, dan menunjuki mereka ke jalan yang lurus." (Al Maidah 15-16)

Insan kamil jika dilihat dari segi fisik biologisnya tidak berbeda dengan manusia lainnya. Namun dari segi mental spiritual ia memiliki kualitas-kualitas yang jauh lebih tinggi dan sempurna dibanding manusia lain. Karena kualitas dan kesempurnaan itulah Tuhan menjadikan insan kamil sebagai khalifah-Nya. Yang dimaksud dengan khalifah bukan semata-mata jabatan pemerintahan lahir dalam suatu wilayah negara (al-khilāfah az-zāhiriyyah) tetapi lebih dikhususkan pada khalifah sebagai wakil Allah (al-khiläfah al-ma'nawiyyah) dengan manifestasi nama-nama dan sifat-Nya sehingga kenyataan adanya Tuhan terlihat padanya.

Di sisi lain, insan kamil dipandang sebagai orang yang mendapat pengetahuan esoterik yang dikenal dengan pengetahuan rahasia ('ilm al-asrār), Ilmu ladunni atau pengetahuan gaib. Jika seseorang telah dapat mengosongkan aql dan qalbnya dari egoisme, keakuan, keangkuhan, dengan keikhlasan total dan kemudian berusaha keras, dengan menyiapkan diri menjadi murid memohon Allah mengajarkan kepadanya kebenaran, dan dengan aktif ia mengikuti aql dan qalbnya merangkaikan berbagai realitas yang hadir dalam berbagai dimensinya, maka Tuhan hadir membukakan pintu kebenaran dan ia masuk ke dalamnya, memasuki kebenaran itu, dan ketika ia keluar, maka ia menjadi dan menyatu dengan kebenaran yang telah dimasukinya. Pengetahuan esoterik adalah karunia (mawhibat) dari Tuhan, setelah seseorang menempuh penyucian diri (tazkiyah an-nafs). Insan kamil juga dipandang sebagai wali tertinggi, atau disebut juga qutb (poros). Dalam struktur hierarki spiritual Sufi, quthb adalah pemegang pimpinan tertinggi dari para wali. Ia hanya satu orang dalam setiap zaman.

Dari kajian di atas dapat dipahami bahwa insan kamil adalah manusia yang mengalami kesempurnaan yang berkedudukan sebagai khalifah dan sebagai wali tertinggi (qutb). Sebagai manusia yang sempurna ia merupakan manifestasi dari nur Muhammad yang menjadi sebab tercipta dan lestarinya alam. Sedangkan dalam kedudukannya sebagai khalifah di bumi ia adalah wakil Tuhan di muka bumi untuk memanifestasikan kemanusiaan, keadilan, dan kedamaian, dan dalam kedudukannya sebagai quthb, ia adalah sumber pengetahuan metafisika yang tidak pernah kekurangan.

Dalam konteks keindonesiaan, insan kamil akan terbentuk jika seseorang mampu mengimplementasikan nilai-nilai yang dianutnya serta mampu bersikap sosial, spiritual dan menempatkan diri di tengah-tengah masyarakat dengan porsi yang seimbang. Porsi yang seimbang tersebut maksudnya, seseorang tersebut mampu menempatkan kepentingan pribadi dan kepentingan masyarakat dengan porsi yang tidak berat sebelah. 


\section{E. Internalisasi Nilai Religius Berbasis Multikultural dalam Membentuk Insan Kamil}

Dalam pengertian yang lebih praktis dan bersifat aplikatif, pendidikan Islam setidaknya memiliki dua substansi, yakni: Pertama, pendidikan Islam adalah aktivitas pendidikan yang didirikan atau diselenggarakan dengan niat dan tujuan untuk mengejawantahkan ajaran dan nilai-nilai Islam. Kedua, pendidikan Islam adalah sistem pendidikan yang dikembangkan dari dan dijiwai oleh ajaran serta nilai-nilai Islam. ${ }^{31}$ Untuk itu, unsur apapun yang akan diintegrasikan atau dikembangkan dalam setiap dimensi pendidikan Islam, harus diarahkan pada konsep dan bentuk-bentuk pendidikan Islam, baik yang bersifat normatif maupun praktis (sistem dan aktivitas).

Kegiatan-kegiatan yang dapat membentuk kepribadian muslim di lingkungan lembaga pendidikan antara lain pertama, melakukan kegiatan rutin, yaitu internalisasi nilai-nilai religius berbasis multikultural secara rutin berlangsung pada hari-hari belajar biasa di lembaga pendidikan. Kegiatan rutin ini dilakukan dalam kegiatan sehari-hari yang terintegrasi dengan kegiatan yang telah diprogramkan, sehingga tidak memerlukan waktu khusus. Pendidikan agama merupakan tugas dan tanggung jawab bersama bukan hanya guru agama saja melainkan juga tugas dan tanggung jawab guru-guru bidang studi lainnya atau sekolah. Pendidikan agama pun tidak hanya terbatas pada aspek pengetahuan, tetapi juga meliputi pembentukan sikap, perilaku, dan pengalaman keagamaan. Untuk itu pembentukan sikap, perilaku, dan pengalaman keagamaan pun tidak hanya dilakukan oleh guru agama, tetapi perlu didukung oleh guruguru bidang studi lainnya.

Kedua, menciptakan lingkungan lembaga pendidikan yang mendukung dan menjadi laboratorium bagi penyampaian pendidikan agama, sehingga lingkungan dan proses kehidupan semacam ini bagi para anak didik benar-benar bisa memberikan pendidikan tentang caranya belajar beragama. Dalam proses tumbuh kembangnya anak didik dipengaruhi oleh lingkungan lembaga pendidikan, selain lingkungan keluarga dan lingkungan masyarakat. Suasana lingkungan lembaga pendidikan dapat menumbuhkan budaya keagamaan.

31 Untuk yang Pertama, dalam prakteknya di Indonesia terdiri atas beberapa jenis, di antaranya adalah: (1) Pondok Pesantren atau Madrasah Diniyah; (2) PAUD/RA, BA, TA, Madrasah dan perguruan tinggi Islam yang bernaung di bawah Kementrian Agama; (3) PAUD/RA, BA, TA, Madrasah dan perguruan tinggi yang berada di bawah naungan yayasan atau organisasi Islam; (4) Pelajaran agama Islam di sekolah/madrasah/perguruan tinggi; dan (5) pendidikan Islam dalam keluarga atau di tempat-tempat ibadah serta forum-forum kajian atau majelis keislaman. Adapun yang Kedua di antaranya mencakup: (1) pendidik/guru/dosen, kepala madrasah/sekolah atau pimpinan perguruan tinggi dan/atau tenaga kependidikan lainnya yang melakukan dan mengembangkan aktivitas kependidikan dengan dilandasi semangat ajaran dan nilai-nilai Islam; (2) komponen-komponen pendidikan lainnya, seperti tujuan, materi/bahan ajar, alat/media/sumber belajar, metode, evaluasi, lingkungan/konteks, manajemen, dan lain-lain yang didasari nilai-nilai Islam. Lihat Muhaimin, et. al., Manajemen Pendidikan: Aplikasi dalam Penyusunan Rencana Pengembangan Sekolah/Madrasah (Jakarta: Kencana, 2009), 3-4. 
Lembaga pendidikan mampu menanamkan sosialisasi dan nilai yang dapat menciptakan generasi-generasi yang berkualitas dan berkarakter kuat, sehingga menjadi pelaku-pelaku utama kehidupan di masyarakat. Suasana lingkungan lembaga ini dapat membimbing anak didik agar mempunyai akhlak mulia, perilaku jujur, disiplin dan semangat sehingga akhirnya menjadi dasar untuk meningkatkan kualitas dirinya.

Ketiga, pendidikan agama tidak hanya disampaikan secara formal oleh guru agama dengan materi pelajaran agama dalam suatu proses pembelajaran, namun dapat pula dilakukan di luar proses pembelajaran dalam kehidupan sehari-hari. Guru bisa memberikan pendidikan agama secara spontan ketika menghadapi sikap atau perilaku anak didik yang tidak sesuai dengan ajaran agama. Manfaat pendidikan secara spontan ini menjadikan anak didik langsung mengetahui dan menyadari kesalahan yang dilakukannya dan langsung pula mampu memperbaikinya. Manfaat lainnya dapat dijadikan pelajaran atau hikmah oleh anak didik lainnya, jika perbuatan salah jangan ditiru, sebaliknya jika ada perbuatan yang baik harus ditiru.

Keempat, menciptakan situasi atau keadaan religius. Tujuannya untuk mengenalkan kepada anak didik tentang pengertian agama dan tata cara pelaksanaan agama tersebut dalam kehidupan sehari-hari. Selain itu juga menunjukkan pengembangan kehidupan religius di lembaga pendidikan yang tergambar dari perilaku sehari-hari dari berbagai kegiatan yang dilakukan oleh guru dan anak didik. Oleh karena itu keadaan atau situasi keagamaan di sekolah yang dapat diciptakan antara lain pengadaan peralatan peribadatan seperti tempat untuk shalat (masjid atau mushalla), alat-alat shalat seperti sarung, peci, mukena, sajadah atau pengadaan al-Quran. Selain itu di ruangan kelas bisa pula ditempelkan kaligrafi, sehingga anak didik dibiasakan selalu melihat sesuatu yang baik. Selain itu dengan menciptakan suasana kehidupan keagamaan di sekolah antara sesama guru, guru dengan anak didik, atau anak didik dengan anak didik lainnya. Misalnya, dengan mengucapkan kata-kata yang baik ketika bertemu atau berpisah, mengawali dan mengakhiri suatu kegiatan, mengajukan pendapatan atau pertanyaan dengan cara yang baik, sopan, santun tidak merendahkan anak didik lainnya, dan sebagainya.

Kelima, memberikan kesempatan kepada anak didik sekolah/madrasah untuk mengekspresikan diri, menumbuhkan bakat, minat dan kreativitas pendidikan agama dalam keterampilan dan seni, seperti membaca al-Quran, adzan, sari tilawah, serta untuk mendorong anak didik sekolah mencintai kitab suci, dan meningkatkan minat anak didik untuk membaca, menulis serta mempelajari isi kandungan al-Quran. Dalam membahas suatu materi pelajaran agar lebih jelas guru hendaknya selalu diperkuat oleh nas-nas keagamaan yang sesuai berlandaskan pada al-Quran dan Hadits Rasulullah saw. Tidak hanya ketika mengajar saja tetapi dalam setiap kesempatan guru harus mengembangkan kesadaran beragama dan menanamkan jiwa keberagamaan yang benar. Guru memperhatikan minat keberagaman anak didik. Untuk itu guru harus mampu menciptakan dan memanfaatkan suasana keberagamaan dengan menciptakan suasana dalam peribadatan seperti shalat, puasa dan lain-lain. 
Keenam, menyelenggarakan berbagai macam perlombaan seperti cerdas cermat untuk melatih dan membiasakan keberanian, kecepatan, dan ketepatan menyampaikan pengetahuan dan mempraktekkan materi pendidikan agama Islam. Mengadakan perlombaan adalah sesuatu yang sangat menyenangkan bagi anak didik, membantu anak didik dalam melakukan kegiatan-kegiatan yang bermanfaat, menambah wawasan dan membantu mengembangkan kecerdasan serta menambahkan rasa kecintaan. Perlombaan bermanfaat sangat besar bagi anak didik berupa pendalaman pelajaran yang akan membantu mereka untuk mendapatkan hasil belajar secara maksimal. Perlombaan dapat membantu para pendidik dalam mengisi waktu kekosongan waktu anak didik dengan sesuatu yang bermanfaat bagi mereka dan pekelahian pelajar dapat dihindarkan. Dari perlombaan ini memberikan kreativitas kepada anak didik dengan menanamkan rasa percaya diri pada mereka agar mempermudah bagi anak didik untuk memberikan pengarahan yang dapat mengembangkan kreativitasnya. Nilai-nilai yang terkandung dalam perlombaan itu antara lain adanya nilai pendidikan di mana anak didik mendapatkan pengetahuan, nilai sosial, yaitu anak didik bersosialisasi atau bergaul dengan yang lainnya, nilai akhlak yaitu dapat membedakan yang benar dan yang salah, seperti adil, jujur, amanah, jiwa sportif, mandiri. Selain itu ada nilai kreativitas dapat mengekspresikan kemampuan kreativitasnya dengan cara mencoba sesuatu yang ada dalam pikirannya.

Salah satu contoh perlombaan adalah lomba berpidato. Anak didik diberikan kesempatan berpidato untuk melatih dan mengembangkan keberanian berkomunikasi secara lisan dengan menggunakan teks atau tanpa teks menyampaikan pesan-pesan Islami. Menjadi ahli pidato yang efektif menuntut para anak didik mengembangkan kemampuannya untuk berkomunikasi secara efektif dan penuh percaya diri, serta mampu merumuskan dan mengkomunikasikan pendapat dan gagasan di dalam berbagai kesempatan dan keadaan. Anak didik diharapkan mampu mendakwahkan ajaran agama yang benar sesuai dengan hukum-hukum agama, tidak sebaliknya berpidato atau berkomunikasi yang merendahkan agama.

Ketujuh, diselenggarakannya aktivitas seni, seperti seni suara, seni musik, seni tari, atau seni kriya. Seni adalah sesuatu yang berarti dan relevan dalam kehidupan. Seni menentukan kepekaan anak didik dalam memberikan ekspresi dan tanggapan dalam kehidupan. Seni memberikan kesempatan kepada anak didik untuk mengetahui atau menilai kemampuan akademis, sosial, emosional, budaya, moral dan kemampuan pribadinya lainnya untuk pengembangan spiritual rokhaninya. Untuk itu pendidikan seni perlu direncanakan dengan baik agar menjadi pengalaman kreatif yang jelas tujuannya. Melalui pendidikan seni, anak didik memperoleh pengalaman berharga bagi dirinya, mengekspresikan sesuatu tentang dirinya dengan jujur dan tidak dibuat-buat. Untuk itu, guru harus mampu menyadarkan anak didik untuk menemukan ekspresi dirinya. Melalui pendidikan seni anak didik dilatih untuk mengembangkan bakat, kreatifitas, kemampuan, dan keterampilan yang dapat ditransfer pada kehidupan. Melalui seni para anak didik akan memperoleh pengalaman dan siap untuk memahami dirinya sendiri secara mandiri. Anak didik yang mandiri 
mampu memahami gaya belajar mereka sendiri, disiplin dalam belajar bukan karena tekanan pihak lain, sehingga mereka mampu mengenali, mengidentifikasi dan memahami kekuatan dan kelemahan kemampuannya mengembangkan bakat dan minatnya. Selain itu juga untuk menghadapi berbagai tantangan, baik dalam belajar maupun dalam kehidupan yang dijalaninya sehari-hari. Anak didik dikondisikan agar mampu mengkomunikasikan apa yang dilihat, didengar, diketahui, atau dirasakannya. Anak didik mampu membuat dan mengembangkan perasaan, imajinasi, dan gagasan secara ekspresif agar menjadi hidup yang berguna bagi pengembangan diri.

Pembelajaran seni di sekolah memiliki kontribusi dalam sikap belajar seumur hidup (life long learning). Selama waktu belajar di sekolah atau di luar waktu belajar, anak didik diharapkan selalu melakukan aktivitas seni untuk mengembangkan pengetahuan, sikap, dan keterampilannya. Oleh karena itu, kurikulum pendidikan seni pada dasarnya dirancang untuk membantu anak didik untuk belajar seumur hidup dengan memiliki pengetahuan, pemahaman, pemikiran, atau komunikasi yang efektif. Melalui pelajaran seni di sekolah, para anak didik dilibatkan untuk menciptakan dan mengekspresikan gagasan dan perasaan dalam bentuk ucapan, tulisan, pendengaran atau gerakannya.

Salah satu bidang seni yang diselenggarakan adalah seni nasyid. Nasyid adalah seni vokal yang kadang-kadang dilengkapi dengan alat musik. Tujuan nasyid antara lain untuk melatih dan mengembangkan keberanian, penjiwaan, keindahan, keserasian dan kemampuan mengaransemen seni modern yang islami. Nasyid mengembangkan kemampuan untuk berfikir dan mengekspresikan diri dalam bentuk vokal atau bunyi-bunyian alat-alat musik. Anak didik belajar untuk menginterpretasikan atau mengekspresikan emosi atau jiwa spiritual di dalam bernyanyi atau bermusik. Dengan bernyanyi atau bermusik anak didik mendapatkan kepuasan lahir dan bathinnya sehingga menjadi landasan yang baik untuk meningkatkan semangat belajarnya. Nasyid biasanya berisikan lagu-lagu atau syair syair manis berupa pujian yang menyenangkan perasaan atau hati. Nasyid ini dapat dijadikan cara yang cukup efektif untuk membantu anak didik dalam memahami berbagai persoalan, seperti tentang kehidupan, rasa cinta kepada sesama manusia atau kepada Tuhan Yang Maha Esa, dan sebagainya. Nasyid dengan menggunakan bahasa dan intonasi yang mudah dipahami mempunyai pengaruh yang baik bagi pertumbuhan jiwa dan bahasa anak didik. Apalagi kalau disertai dengan gerakangerakan yang mudah untuk dilakukan. Serasinya antara suara dengan gerakan atau antara lagu/syair-syair dengan gerakan-gerakan yang mengikutinya dapat menyenangkan perasaan dan menenangkan hati anak didik. ${ }^{32}$

Internalisasi nilai religius berbasis multikultural tidaklah mudah untuk dilakukan, namun sangat urgen untuk dilakukan. Internalisasi nilai tersebut akan membentuk anak didik yang sadar dan menyadari bahwa disamping kebenaran

32Muhammad Fathurrohman, Budaya Religius dalam Peningkatan Mutu Pendidikan: Tinjauan Teoritik dan Praktik Kontekstualisasi Pendidikan Agama di Sekolah (Yogyakarta: Kalimedia, 2015), 108-113. 
yang ada pada dirinya, orang lain juga mungkin benar. Maka dari itu, perlu caracara yang tepat untuk menginternalisasikan nilai religius berbasis multikultural yang kontinyu ke dalam diri peserta didik di suatu lembaga pendidikan, meminjam teorinya Koentjaraningrat tentang wujud kebudayaan, karena dalam menginternalisasikan nilai perlu membentuk kebudayaan yang mapan yaitu, mengupayakan pengembangan dan inovasi dalam tiga aspek, yaitu aspek nilai yang dianut, aspek praktik keseharian, dan aspek simbol-simbol budaya. ${ }^{33}$

Pada aspek nilai yang dianut, perlu dirumuskan secara bersama nilai-nilai agama yang disepakati dan perlu dikembangkan di lembaga pendidikan, untuk selanjutnya membangun komitmen dan loyalitas bersama diantara semua anggota lembaga pendidikan terhadap nilai yang disepakati. ${ }^{34}$ Pada tahap ini diperlukan juga konsistensi untuk menjalankan nilai-nilai yang telah disepakati tersebut dan membutuhkan kompetensi orang yang merumuskan nilai guna memberikan contoh bagaimana mengaplikasikan dan memanifestasikan nilai dalam kegiatan sehari-hari. Pada tahap ini juga disosialisasikan nilai-nilai yang diperlukan untuk diinternalisasikan ke dalam diri peserta didik, serta bagaimana cara menginternalisasikannya.

Dalam aspek praktik keseharian, nilai-nilai religius yang telah disepakati tersebut diwujudkan dalam bentuk sikap dan perilaku keseharian oleh semua warga sekolah. Proses pengembangan tersebut dapat dilakukan melalui tiga tahap, yaitu: pertama, sosialisasi nilai-nilai religius yang disepakati sebagai sikap dan perilaku ideal yang ingin dicapai pada masa mendatang di lembaga pendidikan. Kedua, penetapan action plan mingguan atau bulanan sebagai tahapan dan langkah sistematis yang akan dilakukan oleh semua pihak di lembaga pendidikan yang mewujudkan nilai-nilai religius yang telah disepakati tersebut. Ketiga, pemberian penghargaan terhadap prestasi warga lembaga pendidikan, seperti guru, tenaga kependidikan, dan anak didik sebagai usaha pembiasaan (habit formation) yang menjunjung sikap dan perilaku yang komitmen dan loyal terhadap ajaran dan nilai-nilai religius yang disepakati. Penghargaan tidak selalu berarti materi (ekonomik), melainkan juga dalam arti sosial, cultural, psikologis ataupun lainnya. ${ }^{35}$

Dalam aspek simbol-simbol budaya, pengembangan yang perlu dilakukan adalah mengganti simbol-simbol budaya yang kurang sejalan dengan ajaran dan nilai-nilai agama dengan simbol budaya yang agamis. Perubahan simbol dapat dilakukan dengan mengubah model berpakaian dengan prinsip menutup aurat, pemasangan hasil karya anak didik, foto-foto dan motto yang mengandung pesan-pesan nilai keagamaan. ${ }^{36}$

33 Koentjaraningrat "Kebudayaan, Mentalitas dan Pembangunan" dalam Muhaimin, Nuansa Baru Pendidikan Islam (Jakarta: Raja Grafindo Persada, 2006), 157.

34 Asmaun Sahlan, Mewujudkan Budaya Religius di Sekolah: Upaya Mengembangkan PAI dari teori ke Aksi, (Malang: UIN Maliki Press, 2010), 85.

35Muhaimin, Rekonstruksi Pendidikan Islam: Dari Paradigma Pengembangan, Manajemen Kelembagaan, Kurikulum hingga Strategi Pembelajaran, (Jakarta: Raja Grafindo Persada, 2009), 326.

${ }^{36}$ Sahlan, Mewujudkan Budaya, 86.

Jurnal Pendidikan Agama Islam

Volume 4 Nomor 1 Mei 2016

ISSN(p) 2089-1946\& ISSN(e) 2527-4511

Hal. 130 - 133 
Budaya religius digunakan sebagai wahana internalisasi nilai religius. Hal tersebut dikarenakan internalisasi nilai religius merupakan awal mula dari budaya religius. Budaya religius dibentuk salah satunya dengan pendidikan nilai religius yang dilakukan secara kontinyu oleh suatu lembaga pendidikan, maka akan semua civitas akademika yang ada di lembaga tersebut akan melakukan nilai-nilai religius dan membiasakan dalam kehidupan sehari-hari. Namun, untuk mewujudkan multikultural, maka perlu diterapkan budaya religius yang toleran dan mengajarkan keuniversalitasan nilai religius tersebut.

Penanaman nilai religius mempunyai posisi yang penting dalam upaya membentuk insan kamil pada anak didik. Karena hanya dengan penanaman nilai religius, anak didik akan menyadari pentingnya nilai religius berbasis multikultural dalam kehidupan. Jadi, dalam penanaman nilai-nilai religius tersebut memberikan pemahaman dan kesadaran bahwa nilai-nilai agama tidak hanya dihafal atau hanya berhenti pada wilayah kognisi, akan tetapi juga harus sampai menyentuh aspek afeksi dan psikomotorik bahkan menyentuh aspek saling menghormati antar sesama.

\section{F. Kesimpulan}

Nilai religius multikultural merupakan nilai urgen untuk diinternalisasikan kepada peserta didik. Nilai tersebut akan mampu menjadikan peserta didik menjadi lebih toleran dan lebih religius bahkan mengamalkan ajaran agamanya dan menyentuh afeksi dan psikomotoriknya. Internalisasi nilai religius multikultural dilakukan dengan membentuk budaya religius multikultural sehingga pada akhirnya anak didik akan terbiasa mengamalkan nilai-nilai religius dan akan menjadi anak didik yang menghormati sesamanya bahkan dengan yang lain agama.

\section{G. Referensi}

Abdullah, M. Amin, Pendidikan Agama Era Multi Kultural Multi Religius. Jakarta: PSAP Muhammadiyah, 2005.

Ali, Yunasril, Manusia Citra Ilahi. Jakarta: Paramadina, 1997.

Asmaran, Pengantar Studi Tasawuf. Jakarta:PT Raja Grafindo Persada, 2002.

Badudu, JS, Sutan Muhammad Zain, Kamus Umum Bahasa Indonesia. Jakarta: Pustaka Sinar Harapan, 1996.

Ekosusilo, Madyo, Hasil Penelitian Kualitatif Sekolah Unggul Berbasis Nilai: Studi Multi Kasus di SMAN 1, SMA Regina Pacis, dan SMA al-Islam 01 Surakarta. Sukoharjo: UNIVET Bantara Press, 2003.

Fathiya, Kartika Nur, Problem, Dampak, dan Solusi Transformasi Nilai-Nilai Agama pada Anak Prasekolah. Dinamika Pendidikan No. 1/ Th. XIV / Mei 2007. 
Muh. Khoirul Rifa'i

Fathurrohman, Muhammad, Budaya Religius dalam Peningkatan Mutu Pendidikan: Tinjauan Teoritik dan Praktik Kontekstualisasi Pendidikan Agama di Sekolah. Yogyakarta: Kalimedia, 2015.

Katsoff, Louis O., Elements of Philosophy, terj. Soejono Soemargono. Yogyakarta: Tiara Wacana, 1989.

Koentjaraningrat "Kebudayaan, Mentalitas dan Pembangunan" dalam Muhaimin, Nuansa Baru Pendidikan Islam. Jakarta: Raja Grafindo Persada, 2006.

Langgulung, Hasan, Asas-asas Pendidikan Islam. Jakarta: Pustaka al-Husna, 1993.

Lash, Scott, Mike Featherstone (ed.), Recognition And Difference: Politics, Identity, Multiculture. London: Sage Publication, 2002.

Latif, Abdul, Pendidikan Berbasis Nilai Kemasyarakatan. Bandung: Refika Aditama, 2006.

Marzuki, Pendidikan Agama Islam di Perguruan Tinggi di Perguruan Tinggi Umum dan Pemberdayaan Masyarakat Indonesia. Cakrawala Pendidikan no1 tahun XVI Februari 1997.

Muhaimin, Arah Baru Pengembangan Pendidikan Islam. Bandung: Tarsito, 2003.

Muhaimin, et. al., Manajemen Pendidikan: Aplikasi dalam Penyusunan Rencana Pengembangan Sekolah/Madrasah. Jakarta: Kencana, 2009.

Muhaimin, Rekonstruksi Pendidikan Islam: Dari Paradigma Pengembangan, Manajemen Kelembagaan, Kurikulum hingga Strategi Pembelajaran. Jakarta: Raja Grafindo Persada, 2009.

Mulyana, Rohmat, Mengartikulasikan Pendidikan Nilai. Bandung: Alfabeta, 2004.

Nata, Abuddin, Metodologi Studi Islam. Jakarta: Raja Grafindo Persada, 2003.

Noer, Kautsar Azhari, "Menyemarakkan Dialog Agama (Perspektif Kaum Sufi)", dalam Edy.A.Effendi (ed), Dekonstruksi Islam Madzhab Ciputat. Bandung: Zaman Wacana Mulia, 1999.

Nursyam, Islam Pesisir. Yogyakarta: LKIS, 2005.

Nuruddin, dkk, Agama Tradisional: Potret Kearifan Hidup Masyarakat Samin dan Tengger. Yogyakarta: LKIS, 2003.

Rahman, Budhy Munawar, Islam Pluralis. Jakarta : Paramadina, 2001.

Robbins, S.P., Organizational Behaviour. New Jersey: Prentice Hall, Inc, 1991.

Roibin, Relasi Agama \& Budaya Masyarakat Kontemporer. Malang: UIN Maliki Press, 2009.

Rosyadi, Khoiron, Pendidikan Profetik. Yogyakarta: Pustaka Pelajar, 2004.

Sahlan, Asmaun, Mewujudkan Budaya Religius di Sekolah: Upaya Mengembangkan PAI dari teori ke Aksi. Malang: UIN Maliki Press, 2010. 
Sulistiyorini, Manajemen Pendidikan Islam. Surabaya: eLKAF, 2006.

Tafsir, Ahmad, Ilmu Pendidikan dalam Perspektif Islam. Bandung: Remaja Rosda Karya, 1992.

Taylor, Charles, "The Politics of Recognation" dalam Amy Gutman, Multiculturalism, Examining the Politics of Recognation. Princenton: Princenton University Press, 1994.

Yaqin, M. Ainul, Pendidikan Multikultural (Cross-Cultural Understanding untuk Demokrasi dan Keadilan). Yogyakarta: Pilar Media, 2005. 